\section{E-LOGOS}

ELECTRONIC JOURNAL FOR PHILOSOPHY ISSN 1211-0442

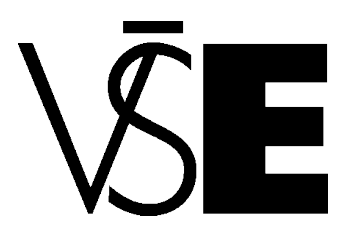

University of Economics

Prague

\title{
Philosophy as a Way of Life in \\ Xenophon's Socrates
}

\author{
Kristian Urstad, Tor Freyr
}

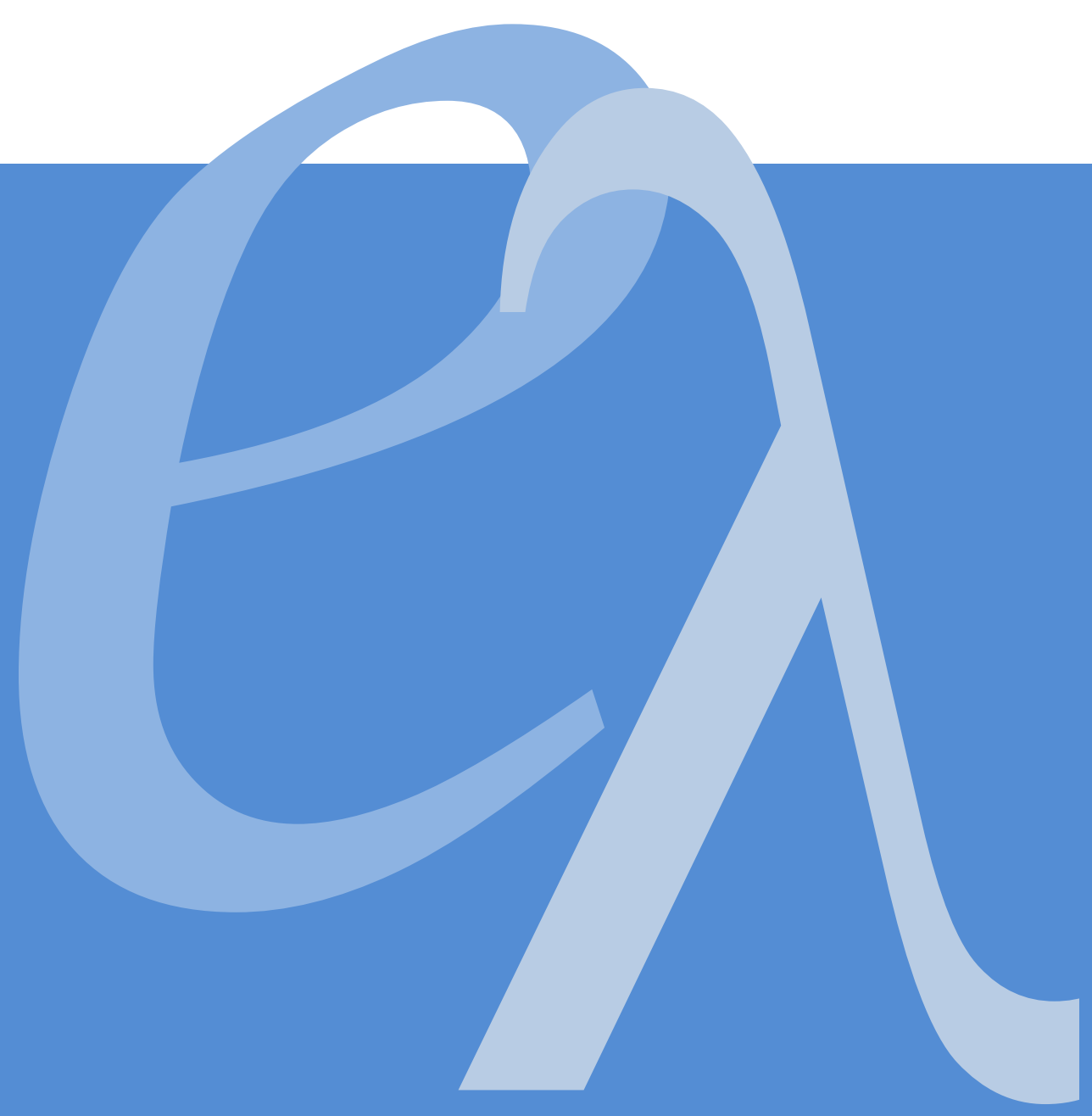




\begin{abstract}
An important idea in antiquity was that to engage in philosophy meant more than the theoretical inquiry into fundamental questions, it was also conceived of as a way of life modelled on the philosophical life of Socrates. In a recent article, John Cooper defends the thesis that, for Socrates and his all successors, the philosophical life meant to live according to reason, understood as the exercising of one's capacity for argument and analysis in pursuit of the truth - which he conceives of as wisdom. It is our contention that an inclusion and close reading of Xenophon's testimony casts doubt on Cooper's unified model of Socrates and his conception of philosophy as a way of life. Xenophon's Socrates, we argue, conceived of the philosophical life as essentially the exercise of one's capacity for self-mastery. Moreover, as we interpret Xenophon, it is this self-mastery, not wisdom, which seems to form the basis or core of Socratic ethics. We try to show that for several of Socrates' philosophical successors living a philosophical life meant something much closer to Xenophon's picture of that life than the one Cooper describes.
\end{abstract}


In his paper, Socrates and Philosophy as a Way of Life, ${ }^{1}$ John Cooper claims that, according to Socrates, as he is refracted through the works of Plato and Xenophon (and other Socratic writers), the philosophical life is fundamentally and simply a life led by reason, and that the good condition of the soul is entirely a matter of one's capacity to, through argument and analysis, explain and defend one's values and to seek truth - a condition, Cooper states, Socrates understands by wisdom.

(1) "We can already see, then, that at the root of this whole development is the idea that to be a philosopher is to be fundamentally committed to the use of one's own capacity for reasoning in living one's life. The philosophical life is essentially simply a life led on that basis." (italics added)

And,

(2) "I said that for Socrates the good condition of the soul is entirely a matter of one's ability, unfalteringly and with an inexhaustible thoroughness, to understand, explain, and defend by argument and analysis, to others and to oneself, one's own values and commitments. This good consists, therefore, in the perfection of the ability to understand and argue well about values. It is the condition in which that ability is made absolutely secure and permanent. That is what Socrates understands by wisdom." (italics added)

The second important aspect of philosophy as a way of life Cooper attributes to Socrates (also as presumed to have been presented in certain dialogues of Plato, Xenophon and other Socratics) is the constitutive and essential grounding role wisdom plays in his conception of the traditional Greek moral virtues.

(3) "But he also thinks that wisdom is the same thing, somehow, as a philosophically explained and articulated version of the traditional Greek virtues of justice, piety, temperance, and courage."

(4) "So, for Socrates, the commitment to the value of wisdom, which expresses itself in a devotion to philosophical examination and self-examination, will also express itself in the resolute avoidance of any vicious act, whether it is one of injustice, or cowardice, or weak self-indulgence."

(5) "For our purposes in offering an account of Socratic philosophy as a way of life, it suffices to point out that on Socrates' view, however we attempt to articulate and explain it, the life of reason, of philosophy, will include a fundamental devotion to the social virtues recognized and prized in Athens and other Greek cities (and, of course, among ourselves

1 This paper was inspired by our attendance at a conference at the University of Oslo where Cooper presented a draft of "Socrates and Philosophy as a Way of Life". 
too): in particular justice, but also physical and moral courage, honesty, self-control..." (italics added)

Finally, Cooper states that this particular model of Socrates leading the philosophical life laid the groundwork for, and defined the conception of, the whole subsequent development of ancient philosophy as a way of life.

(6) "To live a philosophical life is therefore to live consistently on the basis of reason so conceived-philosophical reason, we can say-in everything that we do. But, in a nutshell, both for Socrates and all his successors, this is what being a philosopher and living a philosophical life meant: living according to reason, conceived as a capacity for argument and analysis in pursuit of the truth." (italics added)

Although, as mentioned, Cooper claims to be speaking about Socrates as he was presented through the Socratic writings, he, surprisingly, neglects entirely the testimony of Xenophon (instead relying almost exclusively on Plato's Apology). ${ }^{2}$ In other words, while he asserts that his characterization finds support in both Plato and Xenophon, he never actually goes on to draw from, or even consider, any of the latter's sources. It is our contention that an inclusion and close reading of Xenophon's testimony casts doubt on Cooper's unified model of Socrates and his (Cooper's) conception of philosophy as a way of life. Indeed, we argue that Xenophon actually offers us a distinct version of Socrates' conception of philosophy as a way of life, one that cannot quite be squared with Cooper's claims (as outlined from 1-5). ${ }^{3}$

The Socrates, we argue, that Xenophon presents us with is not someone who makes wisdom, or the exercise of one's capacity for argument and analysis in pursuit of truth, preeminent in, or the entirety of, the philosophical life. Nor, relatedly, is he someone who takes wisdom alone to ground the moral virtues or who sees them as somehow identifiable. Rather, Xenophon's Socrates, we argue, conceived of the philosophical life as essentially the exercise of one's capacity for self-mastery. Moreover, as we interpret Xenophon, it is this self-mastery, not wisdom, which seems to form the basis or core of Socratic ethics. Having established this, we go on to challenge Cooper's claim that all of Socrates' successors in antiquity conceived of the philosophical life in the way he (Cooper) characterizes it (as per 6). We try to

\footnotetext{
${ }^{2}$ It is possible that Cooper's neglect is a consequence of his view, defended elsewhere, that Xenophon is no philosopher $(1999,10)$. But this is a controversial view (see for instance Morrison, 2000; and Dorion, 2006). In any case, Cooper explicitly states that he is drawing from Xenophon in his description of Socrates' philosophy as a way of life $(2007,22)$.

${ }^{3}$ We do not claim that Xenophon's picture of Socrates takes precedence over Plato's, nor do we want to disclaim that the historical Socrates somehow can be construed from the writings of Xenophon and Plato (and other minor Socratics). We simply want to contest that Cooper's Socrates is "the historical Socrates as presumed to have been presented in certain dialogues of Plato, the dialogues of Xenophon, and those of the so-called minor Socratics." (2007: 22)
} 
show that for several of Socrates' philosophical successors living a philosophical life meant something much closer to Xenophon's picture of that life than the one Cooper describes.

Both Plato and Xenophon inform us about Chaerephon's trip to Delphi and his inquiry about Socrates. On the Pythia's response they seem markedly different, however. According to Socrates' account in Plato, Chaerephon

(7) "... asked if any man was wiser than I, and the Pythian replied that no one was wiser (sophos)." (Apology, 21a)

According to Socrates' account in Xenophon, Apollo's reply was that

(8) "no man was more free (eleutherloteron) than I, or more just (dikaioteron) or more prudent (sophronesteron)." (Apology, 14)

What is striking about Xenophon's version is his lack of reference to wisdom (sophia) - an important bit of text and lacuna Cooper never considers. Instead, what we are presented with is a triad of virtues, prudence among them. If, as Cooper argues, wisdom, understood as the use of one's capacity to reason and seek truth, plays such a preeminent role in the philosophical life according to Socrates, we might wonder why it is absent in Xenophon's rendition of the oracle's response. Its omission seems to be made all that more significant when we consider just how foundational and instructive a role the Pythia's response plays in Socrates' mission in life, both according to Plato and Xenophon.

That said, perhaps Xenophon intends prudence (sophrosyne) to be akin to, or interchangeable with, the Platonic Socrates' wisdom (sophia). If he does, we should expect him to clarify this when he makes Socrates go on to interpret the oracle. But this is not what we find. Instead, Socrates is made to explain the oracle's primary meaning in terms of the mastery he has over his appetites and desires, a mastery which he says provides the foundation for the fact that (virtually mirroring the oracle's words) no one is more free (eleutherloteron) and just (dikaioteron) than he is. It is useful to quote the passage in full.

(9) "However, do not believe the god even in this without due grounds, but examine the god's utterance in detail. First, who is there in your knowledge that is less a slave to his bodily appetites than I am? Who in the world more free - for I accept neither gifts nor pay from anyone? Whom would you with reason regard as more just than the one so reconciled to his present possessions as to want nothing beside that belongs to another?" (16) (italics added) 
Though he doesn't mention prudence in his explanation of the oracle's response, it is clear from the context that Socrates takes the self-mastery he professes to have to refer to it. At least in this important bit of text then, it does not seem to be the case that Xenophon's Socrates, in referring to the oracle's designation of prudence, has in mind anything like Plato's wisdom (sophia), of the sort Cooper attributes to Socrates and his conception of philosophy as a way of life (see 1 and 2). ${ }^{4}$

Contextual suggestion aside, is there any corroborating evidence elsewhere in Xenophon where Socrates both gives greater characterization to the self-mastery he hints at and makes explicit this connection, or identification, between it and prudence? After all, the Apology, as Xenophon makes perfectly clear (Apology, 1), was not written to give a comprehensive exposition of Socrates' philosophy, but rather as a compliment to, or correction of, existing testimonies of his trial. Xenophon's richer and more articulated account of Socrates' views are to be found in his Memorabilia and it is here that we find the confirmation we are looking for. ${ }^{5}$ First, at Mem. 1.2.1, Xenophon, nearly echoing the words he puts into the mouth of Socrates at his defence (see 9), describes Socrates as someone "in control of his own passions and appetites". Whereas Socrates in his defence stops short at this description, Xenophon does not. He goes on to say of Socrates that he is therefore the "panton anthropon enkratestatos", the most self-controlled of all humans. We can now go back and give a name to the self-mastery Socrates, in his Apology speech, professes to have - enkrateia. And it is this notion, specifically, that Socrates takes to be synonymous with the prudence (sophrosyne) the oracle attributes to him. Indeed, elsewhere, we see that prudence for Xenophon's Socrates is so closely connected with control of one's desires and passions that he will often use sophrosyne and enkrateia interchangeably. ${ }^{6}$ Consider the following admonition at Mem. 1.3.8.

(10) Of sensual passion he [Socrates] would say: "Avoid it resolutely: it is not easy to control (sophronein) yourself once you meddle with that sort of thing." 7

\footnotetext{
${ }^{4}$ As North points out in her ambitious book Sophrosyne (1966), this particular definition of sophrosyne, i.e. as the control over one's appetites and desires, had become the common view by the late fifth century. For more, according to North, on the near synonymous character of the terms sophrosyne and enkrateia in Xenophon see pgs.128-131; for sophrosyne and its association with, and translation into, prudence, see North (1947).

${ }_{5}$ The last chapter of the Memorabilia exhibits practically the same material as the Apology (Xenophon $1979,639)$. Xenophon thus supplies us with no reason not to cross-reference these two works.

${ }^{6}$ It is worth noting that this usage is by no means uniquely Xenophontic. In a famous passage in Plato's Gorgias (491d), Plato's Socrates claims to side with the common opinion when he identifies the prudent (sophron) and the self-controlled (enkrates) man as he who rules his pleasures and desires. What Plato here describes as the ruling of one's passions, is the equivalent of Xenophon's self-mastery. ${ }^{7}$ In Mem 2.1.1, Xenophon again has Socrates warn against sexual passions, but here he uses enkrateia, "he exhorted his companions to practice self-control (enkrateia) in the matter of ... sexual indulgence ".."
} 
Moreover, the foundational role Socrates, in the Apology, attributes to his sophrosyne with respect to his perfect justice and unparalleled freedom is attested to elsewhere in the Memorabilia - yet with the revealing substitution of a term. That is, Socrates is made to say that it is enkrateia, not sophrosyne, which is responsible for perfect justice and unequalled freedom. For instance, at Mem. 4.5.2-3, he explains to Euthydemus that he must cultivate enkrateia above all things if he wants to possess freedom (eleutheria) - one cannot be free, he warns him, if one is ruled by one's bodily pleasures and appetites.

Contra Cooper then, it does not appear to be the case that Xenophon's Socrates takes wisdom, understood as one's capacity to, through argument and analysis, explain and defend one's values and to seek truth, to be central to his understanding of the philosophical life. Rather, what Socrates' interpretation of the oracle suggests, and what passages elsewhere in Xenophon seem to confirm, is a view of the philosophical life largely characterized by a commitment to the use of one's capacity for self-mastery (enkrateia), where self-mastery is to be understood mainly as the ruling or controlling of one's desires and appetites. ${ }^{8}$ According to Xenophon then, it is this notion of enkrateia, not one's powers of reasoning in pursuit of the truth, that primarily determines the good condition of one's soul and the best way of life. ${ }^{9}$ In other words, the good of philosophy for Xenophon's Socrates, specifically in terms of its application to successful living or the good life, boils down to the exercise of enkrateia within one's soul.

\section{2}

As mentioned at the outset, the second important aspect of philosophy as a way of life Cooper attributes to Socrates is the essential grounding role wisdom plays in his conception of the traditional Greek moral virtues. We believe, however, that a closer reading of Xenophon also casts doubt on this. While wisdom may play a constitutive or preeminent part of Socrates' conception of the moral virtues in Plato, this does not appear to be the case in Xenophon. Instead, what Xenophon continually stresses is Socrates' mastery over the appetites that trouble ordinary people, and which typically motivate unethical conduct. In Xenophon, self-control (enkrateia), not wisdom, forms the basis or core of Socratic ethics. That self-control serves as the foundation of all the moral virtues is stated explicitly by Socrates himself in the Memorabilia:

\footnotetext{
8 This does not mean that Xenophon denies the importance of the capacity to, through argument and analysis, explain and defend one's values. Xenophon clearly thinks that the power of dialectics is a necessary condition for flourishing (eudaimonia), but, unlike Plato, he seems to think that the power of dialectics originates in self-mastery (enkrateia), not wisdom (cf. Mem. 4.5.11-12).

${ }^{9}$ Compare Xenophon's Mem. 1.5.4 (enkrateia is the first thing one ought to establish in one's soul) with Plato's Apology, 30a-b (sophia is the best condition of the human soul).
} 
(11) "Should not every man hold self-control (enkrateia) to be the foundation of all virtue, and first lay this foundation firmly in the soul?" $(1.5 .4 \text {, italics added })^{10}$

More specifically, Xenophon's Socrates takes self-control to be the foundation for the two most important other-regarding Greek virtues, justice and friendship. In a passage we have met before, Socrates tells his jurors:

(12) "Who is there in your knowledge that is less a slave to his bodily appetites than I am? Who in the world more free, for I accept neither gifts nor pay from any one? Whom would you with reason regard as more just than the one so reconciled to his present possessions as to want nothing beside that belongs to another?" (Apology, 16, italics added)

According to Socrates in this passage, injustice seems to come about in the following sort of way. The individual who lacks self-control is constantly in need of money, because he is always looking for the means to satisfy his desires. The danger of injustice here is that he will seize and appropriate the goods of others to satisfy his avariciousness. ${ }^{11}$ On the other hand, the individual who has perfect control over his desires, will have no need for much, money or whatever, and so no need to help himself to the goods of others. In a word, he who needs little and controls his appetites (like Socrates) will not be prompted to commit unjust actions towards others.

Xenophon suggests something similar at Memorabilia 1.2.1. There he says that Socrates could not have corrupted the youth or led others into vice because he was the most self-controlled of all men when it came to his passions and appetites - again signalling the connection between self-control and just actions. He also associates self-control in Socrates with measured (metrion) behaviour. The Greek adjective metrios in this context clearly connotes a moral dimension. Socrates, in Plato's Gorgias (504d), in speaking of doing what is fitting towards other people, or doing the morally appropriate thing or action, does not, as far as we are aware, use the term metrios, but he very well could have, since he does often use variations of the substantives kosmos and taxis (harmony, law, order), clearly synonymous notions. This should serve to reinforce the idea in Xenophon that he who practices self-control is someone who will end up doing things measuredly or in moderation, and so someone who will not be tempted to commit unjust acts towards others.

In considering the connection between self-control and friendship, the second other-regarding virtue, we might turn to Memorabilia 2.6.5. There Socrates and

\footnotetext{
10 See also Mem. 4.5.1 for self-control as the foundation of all the virtues, "... in conversation he exhorted his companions to cultivate self-control (enkrateia) above all things. Thus he bore in mind continually the aids to virtue ..." (italics added)

11 This is how Socrates describes the tyrant. The tyrant lacks enkrateia so he unjustly takes goods from others. See Mem. 4.2.38.
} 
Critobulus discuss what it is we ought to look for if we wanted a good friend. Socrates says that we should look for

(13) "one who controls his indulgence (enkrateia) in the pleasures of the body..." since he is "truly hospitable and fair in his dealings..."

The idea here seems to be that he who lacks self-control is always impinging on others and appealing for help because he is trying to satisfy his desires (see Mem. 2.6.1). On the other hand, the self-controlled individual, he who has limited needs and can be content with little, does not need to satisfy his desires at the expense of others or impinge on those he spends time with, and so can build genuine friendships, based on considerations of hospitality and fairness. ${ }^{12}$

It appears that Cooper is wrong then to attribute to Socrates (the figure he takes to be refracted through the Socratic writers) the idea that wisdom (sophia) is somehow identifiable with the moral virtues or that it alone underpins and expresses itself in the resolute avoidance of unjust or vicious acts (see 3 and 4). Rather, what is central to Xenophon's Socrates' understanding of human excellence is self-mastery (enkrateia). Self-mastery is the foundation of the moral virtues because it emancipates its possessor from the tyranny of his desires and appetites; since the enkrates agent has limited needs and will be content with little, he will neither transgress the demands of justice by appropriating the goods of others nor treat his friends instrumentally or take from them what is theirs. ${ }^{13}$

There is, however, one bit of text which needs to be considered. At Mem. 3.9.5, Xenophon reports that Socrates

(14) "said that justice and every other form of virtue is wisdom (sophia)."

At first glance, this passage appears to make wisdom, not self-control, the very foundation of virtue and seems to bear out the intellectualism of Plato's Socratic ethics, where knowledge or wisdom is sufficient to make a person virtuous, and the impossibility of weakness of will (akrasia) depends only on the presence of wisdom. ${ }^{14}$ However, later, in a related discussion, Socrates is made to tell Euthydemus that, while the incontinent (akrasia) person is as ignorant and stupid as a beast,

(15) "only the self-controlled (enkrateia) have the power to consider the things that matter most, and, sorting them out after their kind, by word and deed alike to prefer the good and reject the evil." (Mem. 4.5.11)

\footnotetext{
12 See Dorion, 2006, for a similar account of the role of enkrateia with respect to the moral virtues in Xenophon.

${ }^{13}$ We are not disclaiming entirely the role of wisdom for the moral virtues. More on this ahead.

14 Socrates in Plato's Protagoras: "Nor is giving into oneself anything other than error, nor controlling onself anything other than wisdom." - 358c (italics added).
} 
Here, the notions of wisdom, or the acquisition of knowledge, and self-control are brought together, but in a way which gives the latter preeminence or more foundational a role. What Socrates seems to be saying is that self-control is a necessary condition and prerequisite of the knowledge of good and bad in life. Indeed Socrates had said as much at Mem. 1.5.5 - every person must first lay this foundation (enkrateia) firmly in their soul if they ever wish to learn anything good or beneficial. Only when the soul has mastered the desires and pleasures that press it to satisfy them, can a person learn anything good or noble. This is not then the intellectualism of Plato's Socratic ethics, where the impossibility of akrasia on the part of the virtuous person is explained purely by the presence of wisdom. Rather, what Socrates is saying, in arguing for what looks to be the impossibility of weakness of will, is that enkrateia is both prior to wisdom and a precondition for acquiring it. In other words, Socrates attributes the impossibility of akrasia on behalf of the virtuous person above all to the possession and exercise of enkrateia rather than to that of wisdom (sophia). Whether Socrates dismisses the role of wisdom altogether in this process is somewhat unclear. Indeed, sometimes Xenophon speaks (about Socrates) as if enkrateia alone is completely effectual when it comes to preventing akrasia. ${ }^{15} \mathrm{~A}$ more likely explanation however is something like the following. In attributing the impossibility of akrasia on the part of the virtuous person chiefly to the presence of enkrateia, Socrates is not excising the role wisdom plays, but simply emphasizing the distinctive and foundational aspect of enkrateia, one on which wisdom depends for its proper perception of good and bad. Upon further analysis then, Mem. 3.9 .5 (14 above) should not be taken to suggest that, according to Xenophon's Socrates, wisdom itself is the foundation of virtue, or in Cooper's words, that a commitment to wisdom alone expresses itself in the resolute avoidance of weak self-indulgence (see 4). While wisdom presumably plays a role in Xenophon's Socrates, it is enkrateia which provides the foundation for the virtuous life - an important aspect Cooper, in his characterization of Socrates (as refracted through the works of the Socratic writers), appears to neglect.

Cooper's claim, that living according to reason, where this is conceived as a capacity for argument and analysis in pursuit of the truth, is what living a philosophical life meant for all of Socrates' successors, is also open to question (see 6). Indeed, we can recognize several of the leading philosophical figures after Socrates as embodying the Socratic paradigm as Xenophon presents it. Self-mastery, not wisdom, is the keynote of the philosophies of, among others, Antisthenes, Diogenes,

15 Xenophon says that Socrates "was so self-controlled that he never chose the pleasanter rather than the better course" (Mem. 4.8.11) 
Aristippus and Zeno. Antisthenes, for instance, seems to have disparaged much theory or learning with respect to moral excellence, emphasizing instead toughness, self-mastery and indifference to sensual pleasures - elements which he no doubt regarded as the essential traits of Socrates' philosophical life. ${ }^{16}$ According to Diogenes Laertius, Zeno (who reportedly read Xenophon's Memorabilia and wished to find men like Socrates - 7. 2-3) became so famous for his enkrateia that he was used in a proverb: "more enkrates than the philosopher Zeno" - meaning, of course, that no one was (7. 27).

Aristippus of Cyrene is an interesting case, not only because he was a friend and close student of Socrates, but because he was a hedonist. We might therefore expect him to have downplayed or departed from features central to his teacher's thought. Yet this is not what we find. For one, not unlike the Socrates Xenophon presents us with, self-mastery lies at the very core of Aristippus' philosophy as a way of life. This might seem somewhat surprising, since according to Xenophon (Mem. 2.1.1-34), Socrates tries to convince Aristippus that he needs to cultivate enkrateia, by arguing that the life of the ruler is superior to that of a slave. Aristippus however, goes on to sidestep the argument by claiming that there is a third option for him, a life neither of rule nor of slavery, but of freedom (eleutheria). It is due to the possession and exercise of this freedom, this ability to adapt to circumstances around him, that he considers himself to be absolutely no candidate for subjugation or slavery. The important point here is that, although he shifts it slightly to suit his philosophical hedonism, Aristippus looks to retain part of the essential feature of self-mastery, or nonsubjugation, from Socrates' keynote virtue. Aristippus, in other words, is clearly interested in a kind of autonomy or self-mastery, and, to that extent, he is not far from the virtue Socrates exhorts him on.

Equally important, though we can only state this briefly and dogmatically, is the role freedom or self-mastery seems to play in Aristippus' moral outlook. A close look at the testimony reveals that Aristippus, though a hedonist, is no crude instrumentalist with respect to the moral virtues or a concern for others. Indeed, apart from a few contentious and unreliable anecdotes, nowhere do we meet with much hint of a breach with social morality on Aristippus' part. Aristippus then, does not appear to take his hedonism to undermine conventional morality. How are we to explain this? The explanation seems to be rooted in his notion of freedom or selfmastery. Aristippus appears to take freedom, conceived of as a kind of self-mastery, as the condition of a kind of indirect form of justice or other-regarding virtue. The person who lacks freedom, conceived of as a kind of self-mastery, is unable to adapt to the circumstances around him, whatever they may be, and so there is the danger that he will help himself to the goods or resources of others to temporarily satisfy his

${ }^{16}$ See Diogenes Laertius 6. 2; see also Kahn, 1996, 7. 
needs or avidity. On the other hand, he, like Aristippus, who possesses this unique form of self-mastery, will always be content or pleased such as he is, whatever state of affairs he finds himself in, and so will simply not have an interest in committing unjust acts. A similar phenonemon seems to hold for the virtue of friendship. Because the Aristippean individual is self-sufficient and content with what is at hand, he will have little need to impinge on those he spends time with, nor invoke in them a sense of mistrust and manipulation, thus jeopardizing their friendship.

So although Aristippus does not appear to endorse enkrateia, at least nominally, he does uphold a very similar account of self-mastery, one which, also not unlike Xenophon's Socrates, he takes to be the preeminent good in his philosophical outlook. His account of self-mastery, moreover, plays a similar role and shares a similar outcome as Socrates' enkrateia in Xenophon. The similarity is this: the one who practices it will have little need, he will not be tempted, to harm or infringe on others. ${ }^{17}$

Though we have been rather brief and perfunctory here, we hope the point is taken. That is, for a number of Socrates' immediate successors, living a philosophical life looks to have meant something much closer to Xenophon's picture of Socrates' philosophical way of life than the one Cooper describes and takes to be representative of philosophy as a way of life tout court after Socrates. ${ }^{18}$

${ }^{17}$ See Urstad, 2009, for more on Aristippus' ethics.

${ }^{18}$ We thank the anonymous referee for the helpful commentary. 


\section{Bibliography}

Cooper, John. "Notes on Xenophon's Socrates." In Reason and emotion : essays on ancient moral psychology and ethical theory, 3-28. Princeton N.J.: Princeton University Press, 1999.

Cooper, John M. "Socrates and Philosophy as a way of life." In Maieusis : essays in ancient philosophy in honour of Myles Burnyeat, edited by Dominic Scott, 20-44. Oxford ; New York: Oxford University Press, 2007.

Diogenes, Laertius. 1979. Lives of the eminent philosophers. Trans. R. D. Hicks. Cambridge Mass. ;London: Harvard University Press; Heinemann.

Dorion, Louise Andre. "Xenophon's Socrates." In A companion to Socrates, edited by Sara Ahbel-Rappe, 93-109. Pbk. ed. Chichester West Sussex; Malden Mass.: Wiley-Blackwell, 2009.

Kahn, Charles. 1999. Plato and the Socratic dialogue. Cambridge: Cambridge University Press.

Morrison, D. “On Professor Vlastos' Socrates.” In The Socratic problem and Socratic ignorance., edited by William Prior. 1. ed. London [u.a.]: Routledge, 2000.

North, H. 1947. "A Period of Opposition to Sophrosyne in Greek Thought" Transactions and Proceedings of the American Philological Association. Vol. 78. 1-17.

North, H. 1966. Sophrosyne: self-knowledge and self-restraint in Greek literature. Ithaca, NY: Cornell University Press

Plato. "Apology." In Euthyphro Apology Crito Phaedo Phaedrus, edited by Jeffrey Henderson, translated by Harold North Fowler. London: Harvard University Press, 1977.

Plato. "Gorgias." In Lysis; Symposium; Gorgias, edited by G. P. Goold, translated by W.R.M. Lamb, 249-533. London: Harvard University Press, 1996.

Urstad, Kristian. "Pathos, Plaesure and the Ethical Life in Aristippus." Electronic Jounal for Philosophy. e-logos.vse.cz, 2009.

http:/ / e-logos.vse.cz/index.php?article=256.

Xenophon. 1979. Apology. In Memorabilia and Oeconomicus Symposium and Apology, ed. G. P. Goold, trans. O.J. Todd, 637-663. Cambridge (Mass.); London: Harvard university press; $\mathrm{W}$. Heinemann. 
Xenophon. 1979. Memorabilia. In Memorabilia and Oeconomicus Symposium and Apology, ed. G. P. Goold, trans. E.C. Marchant, 1-359. Cambridge (Mass.); London: Harvard university press; W. Heinemann. 


\section{E-LOGOS}

ELECTRONIC JOURNAL FOR PHILOSOPHY

Ročník/Year: 2010 (vychází průběžně/ published continuously)

Místo vydání/Place of edition: Praha

ISSN 1211-0442

Vydává/Publisher:

Vysoká škola ekonomická v Praze / University of Economics, Prague

nám. W. Churchilla 4

Czech Republic

13067 Praha 3

IČ: 61384399

Web: http://e-logos.vse.cz

Redakce a technické informace/Editorial staff and technical information:

Miroslav Vacura

vacuram@vse.cz

Redakční rada/Board of editors:

Ladislav Benyovszky (FHS UK Praha, Czech Republic)

Ivan Blecha (FF UP Olomouc, Czech Republic)

Martin Hemelík (VŠP Jihlava, Czech Republic)

Angelo Marocco (Pontifical Athenaeum Regina Apostolorum, Rome, Italy)

Jozef Kelemen (FPF SU Opava, Czech Republic)

Daniel Kroupa (ZU Plzeň, Czech Republic)

Vladimír Kvasnička (FITT STU Bratislava, Slovak Republic)

Jaroslav Novotný (FHS UK Praha, Czech Republic)

Jakub Novotný (VŠP Jihlava, Czech Republic)

Ján Pavlík (editor-in-chief) (VŠE Praha, Czech Republic)

Karel Pstružina (VŠE Praha, Czech Republic)

Miroslav Vacura (executive editor) (VŠEE Praha, Czech Republic) 